\title{
MODAL SOSIAL KELOMPOK TANI “CITAWAYA" DI DESA TALIKURAN I, KECAMATAN SONDER, KABUPATEN MINAHASA
}

\author{
Stefanny K. Kawulur \\ Benu Olfie L. S. \\ Agnes E. Loho
}

\begin{abstract}
The objective of this research is to know sosial capital of "Citawaya" farmer group in Village of Talikuran I, Sub-district of Sonder, Minahasa Regency. The study lasted for three months starting from February until April 2017. The data used are primary data collected through interviews on all members of farmer group "Citawaya" which amounted to 20 people as respondents. Secondary data obtained from Talikuran I Village Offices. The analysis used is descriptive through Likert Scale and presented in tabular form. The results showed that "Citawaya" farmer group in the Village of Talikuran I had a very high social capital of trust, social norms, social network, social values, and reciprocity by obtaining social capital index $85 \%$. The highest social capital was trust indicators, then it followed by reciprocity indicators then social network indicators, then indicators of social values and recent indicators of social norms. The high social capital makes the "Citawaya" farmer group able to survive until now and bring a good changing in the group.
\end{abstract}

Keywords : social capital, farmer groups, Village Talikuran I, Sonder Sub-district, Minahasa Regency

\begin{abstract}
ABSTRAK
Penelitian ini bertujuan untuk mengetahui modal sosial kelompok tani "citawaya" di Desa Talikuran I Kecamatan Sonder Kabupaten Minahasa. Penelitian berlangsung selama 3 (tiga) bulan mulai dari Bulan Februari 2017 sampai Bulan April 2017. Data yang digunakan yaitu data primer yang dikumpulkan melalui wawancara pada semua anggota kelompok tani "citawaya" yang berjumlah 20 orang sebagai responden. Data sekunder diperoleh dari Kantor Desa Talikuran I. Analisis yang digunakan yaitu secara deskriptif melalui Skala Likert dan disajikan dalam bentuk tabel. Hasil penelitian menunjukkan bahwa kelompok tani "citawaya" di Desa Talikuran I memiliki modal sosial yang sangat tinggi yaitu kepercayaan, norma-norma sosial, jaringan sosial, nilai-nilai sosial, dan timbal balik dengan mendapatkan indeks modal sosial $85 \%$. Modal sosial yang paling tinggi ada pada indikator kepercayaan, kemudian diikuti dengan indikator timbal balik, kemudian indikator jaringan sosial, kemudian indikator nilai-nilai sosial, dan terakhir indikator norma sosial. Tingginya modal sosial membuat kelompok tani "Citawaya" bisa bertahan sampai sekarang dan membawa perubahan yang baik dalam kelompok.
\end{abstract}

Kata kunci: modal sosial, kelompok tani, Desa Talikuran I, Kecamatan Sonder, Kabupaten Minahasa. 


\section{PENDAHULUAN}

\section{Latar Belakang}

Indonesia merupakan negara berkembang yang terus mengupayakan pembangunan. Tujuan dari pembangunan adalah untuk memperbaiki dan meningkatkan kesejahteraan masyarakat, serta menciptakan inovasi didalam masyarakat tersebut. Tanggung jawab utama dalam program pembangunan adalah masyarakat memiliki kekuatan atau kemampuan. Kekuatan yang dimaksud dapat dilihat dari aspek fisik, material, ekonomi, kelembagaan, kerjasama, kekuatan intelekual dan komitmen bersama. Terkait dengan pembangunan, bahwa tujuan yang ingin dicapai adalah untuk membentuk individu dan kelompok masyarakat dalam hal ini kelompok tani menjadi mandiri, kemandirian tersebut meliputi kemandirian berpikir, bertindak dan mengendalikan apa yang mereka lakukan. Dengan potensi yang dimiliki seseorang atau sekelompok orang diharapkan dapat mendayagunakan kekuatan yang dimiliki untuk mengakses informasi, teknologi, modal, mengembangkan ketrampilan dalam menemukan solusi kehidupan. Indonesia adalah negara agraris dengan kondisi alam yang mendukung, lahan yang luas dan beriklim tropis dimana sinar matahari terjadi setiap tahun sehingga bisa bercocok tanam. Pertanian merupakan salah satu sektor utama sebagai mata pencaharian penduduk di Provinsi Sulawesi Utara khususnya Kabupaten Minahasa. Sehubungan dengan itu para petani di Desa Talikuran I membentuk kelompok tani. Kelompok tani adalah merupakan suatu organisasi pemberdayaan masyarakat.

Di Talikuran I ada 4 (empat) kelompok tani yaitu, Citawaya tingkatannya (madya), Karya Lestari (pemula), Sinar Lalek ( pemula), dan Melati (pemula). Jenis usaha tani yang dikelolah oleh kelompok tani Citawaya adalah komoditi padi, jagung, dan cabe. Kelompok tani memerlukan apa yang disebut modal (capital) yang merupakan landasan suatu usaha. Ada modal sumberdaya alam, (Pongtuluran, 2015) menyatakan sumberdaya alam adalah unsur lingkungan hidup yang terdiri atas sumber daya hayati dan nonhayati yang secara keseluruhan membentuk kesatuan ekosistem, sumberdaya alam tidak semata-mata diartikan untuk memenuhi taraf hidup manusia dalam arti material, tetapi juga memungkinkan bagi setiap orang untuk mengadakan pilihan dalam ragam kegiatan hidupnya. Untuk memenuhi hal tersebut perlu ditunjang dengan kualitas sumberdaya manusia. Theresia, dkk (2014) mengartikan sumberdaya manusia adalah seperangkat kecakapan, pengetahuan, sifat sosial, dan kepribadian, termasuk kreativitas, yang terkandung dalam diri manusia yang dapat diupayakan untuk melaksanakan kegiatan yang dapat menghasilkan atau memberikan manfaat ekonomi. Ada juga modal yang berperan penting dalam kelompok tani yaitu modal sosial.

Mudiarta (2009) mendefinisikan modal sosial sebagai sumberdaya yang muncul dari adanya relasi sosial dan dapat digunakan sebagai perekat sosial untuk menjaga kesatuan anggota kelompok dalam mencapai tujuan bersama, ditopang oleh adanya kepercayaan, dan norma sosial yang dijadikan acuan bersama dalam bersikap, bertindak dan berhubungan satu sama lain. Dalam penelitian ini lebih cenderung kepada modal sosial karena merupakan sumberdaya sosial yang dapat dipandang sebagai investasi untuk mendapatkan sumberdaya baru dalam masyarakat, dan modal sosial diyakini sebagai komponen utama dalam menggerakkan kebersamaan, ide, saling percaya, dan saling menguntungkan untuk mencapai kemajuan bersama. Kelompok tani Citawaya adalah kelompok tani yang berkembang di Desa Talikuran I, maka peneliti memilih kelompok tani Citawaya untuk mengetahui apakah modal sosial merupakan alasan atas berkembangya kelompok tani ini, Kelompok tani Citawaya terbentuk pada Tahun 1997 yang beranggotakan 17 orang serta pengurus (Ketua, Sekretaris, dan Bendahara) 3 orang, jadi total berjumlah 20 orang. Berdasarkan latar belakang yang diuraikan maka penting untuk mengetahui modal sosial dalam kelompok tani Citawaya sebagai acuan bagi kelompok tani lainnya. Karena Kelompok Tani Citawaya adalah kelompok tani yang berkembang diantara kelompok tani lainnya yang ada di Desa Talikuran I. 


\section{Rumusan Masalah}

Berdasarkan latar belakang yang telah diuraikan maka rumusan masalah dalam penelitian ini adalah bagaimana modal sosial Kelompok Tani Citawaya di Desa Talikuran I Kecamatan Sonder Kabupaten Minahasa.

\section{Tujuan Penelitian}

Berdasarkan pada rumusan masalah yang diangkat maka penelitian ini bertujuan untuk mengetahui modal sosial pada Kelompok Tani Citawaya di Desa Talikuran I Kecamatan Sonder Kabupaten Minahasa.

\section{Manfaat Penelitian}

Penelitian ini diharapkan dapat memberikan kontribusi kepada para petani terlebih khusus anggota Kelompok Tani Citawaya, untuk mengetahui modal sosial yang terdapat dalam kelompok tani di Desa Talikuran I dan menjadi bahan masukan bagi kelompok tani lainnya.

\section{METODOLOGI PENELITIAN}

\section{Waktu Dan Lokasi Penelitian}

Penelitian ini dilaksanakan di Desa Talikuran I Kecamatan Sonder Kabupaten Minahasa selama 3 (tiga) Bulan mulai dari Bulan Februari 2017 sampai Bulan April 2017 mulai dari persiapan, pengambilan data sampai pada penyusunan laporan hasil penelitian.

\section{Metode Pengumpulan Data}

Metode pengumpulan data dalam penelitian ini menggunakan data primer dan data sekunder. Data primer diperoleh dari wawancara langsung pada anggota kelompok tani "Citawaya" dengan menggunakan daftar pertanyaan yang telah disiapkan berupa kuisioner. Data sekunder diperoleh dari lembaga yang terkait dengan masalah penelitian yaitu pemerintah Desa Talikuran I.

\section{Metode Pengambilan Sampel}

Populasi dalam penelitian ini yaitu semua anggota kelompok tani "Citawaya" yang berjumlah 20 orang responden diambil seluruh anggota dalam kelompok tani ini sudah termasuk didalamnya ketua kelompok tani, sekretaris, dan bendahara.

\section{Konsep Pengukuran Variabel}

Variabel, Sub Variabel dan Indikator penelitian yang dikaji dalam penelitian ini adalah:

1. Karakteristik Kelompok Tani

1) Nama Kelompok Tani

2) Tahun Terbentuk

3) Keanggotaan

4) Jenis Usaha

2. Karakteristik Responden

1) Umur anggota Kelompok Tani (dalam tahun)

2) Tingkat Pendidikan formal responden

3) Pekerjaan responden

3. Modal Sosial

1) Kepercayaan

Kepercayaan adalah kemauan seseorang untuk bertumpu pada orang lain dimana seseorang memiliki perasaan yakin bahwa yang lain akan melakukan sesuatu seperti yang diharapkan dan akan bertindak dalam suatu tindakan yang mendukung. Kepercayaan meliputi:

a. Kepercayaan: antara dua orang atau lebih.

1. Ada saling percaya antar sesama anggota Kelompok Tani Citawaya.

2. Ada saling percaya antar Kelompok Tani Citawaya dengan Kelompok Tani yang lain.

3. Ada saling percaya antar Kelompok Tani Citawaya dengan Pemerintah.

b. Harapan: yang akan terkandung dalam hubungan itu, yaitu tidak akan merugikan salah satu atau kedua belah pihak.

1. Masing-masing anggota kelompok memiliki sikap yang jujur

2. Kerjasama yang baik antar sesama anggota Kelompok Tani Citawaya.

3. Anggota Kelompok tidak dirugikan dalam menjalankan usaha tani. 
c. Interaksi Sosial: Interaksi sosial memungkinkan hubungan dan harapan itu dapat terwujud.

1. Saling memberikan pendapat atau masukan terhadap sesama anggota Kelompok.

2. Masing-masing anggota kelompok memiliki sifat terbuka satu sama lain yaitu saling memberikan informasi terkait kegiatan pertanian dan pengetahuan tentang pertanian

3. Masing-masing anggota kelompok tani Citawaya dapat menerima pendapat orang lain.

\section{2) Norma Sosial}

Norma adalah aturan yang mengatur tingkah laku individu dalam masyarakat. Aturan tersebut mengikat bagi setiap individu yang hidup dalam lingkungan berlakunya norma tersebut. Dalam arti setiap orang yang hidup dalam lingkungan berlakunya norma tersebut harus menaatinya. Variabel pengukuranya adalah:

a. Peraturan:

1. Anggota kelompok memiliki sifat taat terhadap aturan yang berlaku.

2. Aturan yang berlaku membawa dampak yang baik dalam kelompok.

3. Anggota kelompok tidak berlaku curang.

b. Sanksi: Sanksi tegas terhadap anggota kelompok tani yang tidak taat peraturan.

1. Anggota kelompok yang tidak taat aturan diberikan sanksi.

2. Anggota kelompok yang melakukan pelanggaran siap menerima sanksi yang berlaku.

3. Sanksi membawah perubahan yang baik terhadap kelompok.

c. Keadilan: Pengambilan keputusan yang adil dari Ketua Kelompok Tani Citawaya terhadap anggota kelompoknya.

1. Pembagian bantuan yang adil untuk anggota oleh Ketua Kelompok Tani.

2. Ketua Kelompok Tani berlaku adil apabila ada anggota kelompok yang tidak taat terhadap peraturan maka akan diberikan sanksi dengan tidak memandang siapa dia, seperti contoh Sekertaris, bendahara kelompok atau saudara dari Ketua Kelompok Tani.

3. Pembagian tugas yang merata pada setiap anggota kelompok.

3) Jaringan Sosial

Jaringan adalah sebuah pola koneksi dalam hubungan sosial individu dan kelompok untuk menyatukan diri dalam hubungan untuk mencapai tujuan bersama.

a. Jaringan antar Petani dengan Petani dalam Kelompok Tani Citawaya

b. Jaringan antar Petani Citawaya dengan masyarakat dan antar petani dengan pembeli hasil usaha tani

c. Jaringan Petani Citawaya dengan Pemerintah

4) Nilai-Nilai Sosial

a. Kerja Keras

1. Aktivitas dalam kelompok.

2. Kerajinan masing-masing anggota kelompok.

3. Anggota kelompok tidak putus asa dalam menjalankan usaha tani.

b. Keharmonisan

1. Ada hubungan yang selaras dan serasi pada anggota-anggota Kelompok Tani Citawaya sehingga hak dan kewajiban dapat terwujud dengan nilai-nilai sosial, dan peratuan yang berlaku.

2. Dapat menyatukan perbedaanperbedaan pendapat dari setiap anggota.

3. Ada keharmonisan disetiap anggota kelompok.

c. Prestasi

1) Pernah mendapatkan penghargaan dari pemerintah.

2) Kelompok Tani Citawaya pernah mencapai prestasi.

3) Kelompok Tani Citawaya adalah

4) Kelompok Tani yang berkembang di Desa Talikuran I

5) Timbal Balik (Reciprocity)

a. Tingkat Kepedulian Sosial 
1. Peka terhadap kebutuhan anggota kelompok.

2. Peka terhadap kebutuhan kelompok lain.

3. Peka terhadap kebutuhan masyarakat diluar kelompok.

b. Sikap Saling Membantu

1. Saling membantu dalam kelompok.

2. Saling membantu dengan kelompok yang lain.

3. Saling membantu dengan masyarakat diluar kelompok.

c. Sikap Saling Memperhatikan

1. Saling mendorong antara sesama anggota kelompok kearah yang lebih baik.

2. Saling mendorong antara kelompok tani Citawaya dengan kelompok lain.

3. Saling melindungi satu sama lain.

\section{Analisis Data}

Analisis data yang digunakan pada penelitian ini adalah analisis deskriptif, yang disajikan dalam bentuk tabel. Data yang dihasilkan dianalisis dengan menggunakan skala likert. Mengukur variabel penelitian yang digunakan maka dilakukan pengukuran dengan cara menguraikan indikator-indikator variabel dalam bentuk item-item pernyataan yang disusun dalam bentuk kuesioner dengan bobot nilai (skor) jawaban 1-5, untuk membantu analisa data digunakan skor, Sangat Tinggi (skor 5), Tinggi (skor 4), Sedang (skor 3), Rendah (skor 2), Sangat Rendah (skor 1). Memperoleh nilai total masing-masing variabel adalah dengan menjumlahkan nilai-nilai dari item pernyataan dan kemudian dibagi dengan jumlah item pernyataan. Nilai variabel tersebut digolongkan dalam beberapa kategori yang didasarkan pada skala likert. Riduwan (2012)

Dengan cara perhitungan skor masing-masing pernyataan:

Jumlah skor tiap kriterium $=$ Capaian skor $\mathrm{X}$ Jumlah responden

Skor $5=5$ x $20=100$

Skor $4=4 \times 20=80$

Skor $3=3 \times 20=60$

Skor $2=2 \times 20=40$

Skor $1=1 \times 20=20$

Jumlah skor ideal untuk setiap pernyataan (skor tertinggi) $=100$
Jumlah skor terendah $=20$

Dengan interpretasi nilai :

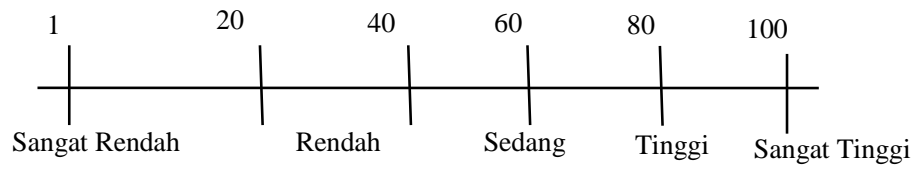

Gambar 1. Interpretasi Nilai Jumlah Skor Tiap Kriterium Pernyataan

Cara pengukuran skor keseluruhan untuk mengetahui Modal Sosial pada Kelompok Tani Citawaya yaitu:

Jumlah skor seluruh kriterium = Capaian jumlah skor X Jumlah Responden X instrument pernyataan

Skor $5=5 \times 20 \times 40=4.000$

Skor $4=4 \times 20 \times 40=3.200$

Skor $3=3 \times 20 \times 40=2.400$

Skor $2=2 \times 20 \times 40=1.600$

Skor $1=1$ × 20 x $40=800$

Jumlah skor ideal untuk keseluruhan pernyataan $=4.000$

Jumlah skor terendah $=800$

Dengan interpretasi nilai:

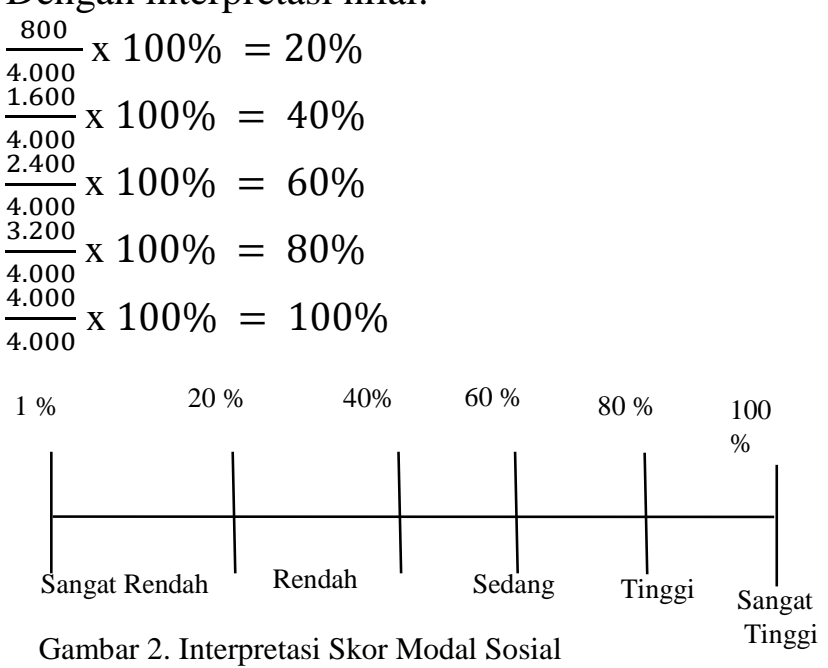

Keterangan kriterium interpretasi skor Modal Sosial :

Angka 1\%-20\% = Sangat Rendah

Angka 21\% - 40\% = Rendah

Angka $41 \%-60 \%=$ Sedang

Angka $61 \%-80 \%=$ Tinggi

Angka $81 \%-100 \%=$ Sangat Tinggi

Modal Sosial Kelompok Tani $=$ Jumlah skor hasil pengumpulan data

Jumlah skor ideal 


\section{HASIL DAN PEMBAHASAN}

\section{Deskripsi Wilayah Penelitian}

\section{Sejarah Desa Talikuran I}

Nenek moyang masyarakat Sonder berasal dari Kiawa yang datang sekitar tahun 1100 yang dipimpin oleh Dotu Najoan dan Dotu Sendow dan menempati hamparan yang diberi nama Rama. Kemudian mereka berpindah lagi ke Utara, tempat yang baru ini kemudian dikenal dengan nama Mawale, dari Mawale mereka berpindah lagi ke Utara ke tempat yang kemudian dikenal dengan nama Kekeseen (sekarang sekitar SD Inpres Talikuran). Dari Kekeseen masyarakat Sonder mulai berpencar-pencar dan mendirikan pemukiman-pemukiman baru. Setelah terjadi perpisahan maka tempat yang ditinggalkan ini mereka sebut Pinetalicuran yang artinya tempat berpisah / tempat yang ditinggalkan (dari kata dasar Licur = belakang, Licuran menjadi Pinetalicuran $=$ tempat berpisah $/$ tempat yang ditinggalkan). Lama kelamaan nama ini disebut "Talicuran", setelah pemerintah Belanda mengakui / meresmikan desa-desa di Kecamatan Sonder yaitu pada saat pemerintah Belanda meresmikan Desa Sonder kira-kira 1837 maka kata/nama "Talicuran" diubah menjadi "Talikuran" dan pusat pemerintahan Sonder waktu itu adalah Talikuran. Terbentuknya Desa Talikuran I berdasarkan pemekaran Desa Talikuran pada tahun 2012 di masa pemerintahan Hukum Tua Yerry Tambuwun. Desa Talikuran I termasuk di 19 Desa yang ada di Kecamatan Sonder dan merupakan Desa yang masih berumur muda.

\section{Letak Geografis}

Desa Talikuran I adalah sebuah Desa yang terletak di Wilayah Kecamatan Sonder, Kabupaten Minahasa, Provinsi Sulawesi Utara. Terdiri dari 3 Jaga/Dusun dengan batas wilayah :

Sebelah Utara

Sebelah Timur

: Desa Rambunan

Sebelah Selatan

: Desa Talikuran

Sebela Barat
: Desa Kauneran Satu

: Tincep
Luas Wilayah Desa Talikuran I memanjang dari Timur ke Barat dengan luas 102 Hektar, beriklim tropis dan berada pada ketinggian 565 meter diatas permukaan laut sehingga Desa Talikuran I termasuk daerah dataran tinggi di Minahasa.

\section{Keadaan Penduduk}

Total keseluruhan jumlah penduduk yang ada di Desa Talikuran I sebanyak 712 jiwa, dengan jumlah Kepala Keluarga sebanyak 238. Tabel 1 menunjukkan bahwa jumlah penduduk berjenis kelamin laki-laki (53\%) lebih besar dari pada penduduk dengan jenis kelamin perempuan (47\%). Tabel 2 menunjukkan bahwa sebagian besar penduduk di Desa Talikuran I belum memperoleh pendidikan yang cukup karena sebagian besar berpendidikan pada tingkat SD dengan persentase 33,49\% dan tingkat SMP 14,35\% sedangkan untuk tingkat SMA $16,75 \%$ dan perguruan tinggi hanya $11,96 \%$, tamat diploma $1,44 \%$, tamat $\mathrm{S} 17,18 \%$ dan yang tamat $\mathrm{S} 2$ $0.48 \%$. Tabel 3 menunjukkan bahwa sebagian besar penduduk di Desa Talikuran I bermata pencaharian sebagai petani dengan jumlah 110 orang atau sebesar $34 \%$, buruh tani 42 orang atau sebesar $13 \%$ dan peternak 66 orang atau sebesar 20\%, di Desa Talikuran I sebagian besar penduduk bermata pencaharian sebagai petani dan buruh tani karena merupakan Daerah yang subur, hasil pertanian yang ada yaitu padi sawah, cabai, dan jagung, juga sebagian besar bermata pencaharian sebagai peternak. Hal ini menujukkan bahwa perekonomian masih bersifat agraris yang ditunjukkan oleh banyaknya penduduk yang bekerja pada sektor pertanian.

\section{Deskripsi Kelompok Tani "Citawaya"}

\section{Sejarah Kelompok Tani Citawaya}

Kelompok Tani Citawaya berdiri pada Tahun 1998 yang dibentuk oleh sekumpulan petani yang ingin maju dan membentuk wadah kelompok tani, alasan lain dibentuknya kelompok tani ini adalah supaya para petani dapat berdiskusi tentang pertanian dan banyak mendapat informasi yang baru. Kelompok tani Citawaya dibentuk saat itu masih di Desa Talikuran belum dimekarkan menjadi Desa Talikuran I. 


\section{Anggaran Dasar Kelompok Tani Citawaya}

Nama, Tempat, Kedudukan, dan Ruang Lingkup

1. Perkumpulan Kelompok Tani ini bernama "Citawaya"

2. Dalam anggaran dasar ini disebut kelompok tani Citawaya yang berkedudukan di:
Desa
: Talikuran I
Kecamatan
: Sonder
Kabupaten
: Minahasa

3. Ruang lingkup Kelompok Tani Citawaya meliputi: petani yang berdomisili di Desa Talikuran I.

\section{Azas dan Tujuan Kelompok Tani "Citawaya"}

1. Kelompok Tani Citawaya berazaskan gotong royong, saling percaya, dan kebersamaan.

2. Kelompok Tani Citawaya memiliki tujuan sebagai berikut:
a. Meningkatkan produktivitas usaha anggota kelompok dengan menerapkan teknologi yang tepat dan memanfaatkan sumberdaya alam secara optimal
b. Kerjasama kelompok yang mencerminkan tingkat produktivitas usaha para anggota
c. Partisipasi anggota dalam kegiatan secara demokratis
d. Pendidikan, pelatihan, dan informasi
e. Kerjasama antar kelompok
f. Kepedulian terhadap sesama anggota kelompok dan masyarakat lain

\section{Fungsi dan Peran Kelompok Tani}

Fungsi dan peran kelompok tani:

1. Sebagai lembaga dan wadah kegiatan pertanian

2. Membangun dan mengembangkan potensi yang dimiliki anggota yang membawa dampak positif untuk meningkatkan usaha dan pendapatan

3. Mendorong dan membantu kegiatan usaha yang dijalankan oleh anggota

4. Mengkoordinir kegiatan pertanian yang dijalankan

\section{Keanggotaan}

1. Anggota kelompok tani adalah merupakan pemilik dan sebagai pengguna kegiatan serta usaha yang dijalankan kelompok
2. Yang dapat diterima menjadi anggota adalah mereka (para petani) yang mempunyai kegiatan usaha tani di Desa Talikuran I

3. Keanggotaan didasarkan atas kesadaran, kerelaan, dan kesungguhan untuk ikut berperan aktif dalam kegiatan kelompok tani

4. Penerimaan dan pemberhentian anggota kelompok ditentukan oleh rapat anggota kelompok dan rapat-rapat khusus yang diselenggarakan dengan memperhatikan usul dan saran dari Penasehat dan Pembina

\section{Hak dan Kewajiban Anggota}

Setiap anggota memiliki hak :

1. Menerima dan menggunakan bantuan dalam bentuk apapun

2. Menghadiri, menyatakan pendapat, dan memberikan suara dalam rapat anggota

3. Untuk memilih dan dipilih sebagai pengurus

4. Memahami dan mengetahui pembukuan kelompok pada saat rapat anggota

5. Mendapatkan fasilitas dan pelayanan yang sama dari kegiatan usaha yang dijalankan kelompok

6. Mendapat sisa hasil penyelesaian apabila kelompok dibubarkan atau berhenti dari keanggotaan

Setiap anggota memiliki kewajiban :

1. Menjunjung tinggi nama dan kehormatan kelompok tani

2. Mematuhi ketentuan yang ada dalam anggaran dasar dan anggaran rumah tangga, keputusan-keputusan rapat serta peraturan khusus yang telah disepakati dalam rapat anggota

3. Membayar simpanan iuran kelompok yang telah disepakati

4. Menanggung resiko usaha yang dijalankan

Berakhirnya Keanggotaan Bilamana :

1. Kelompok dibubarkan

2. Berhenti atas permintaan sendiri atau mengundurkan diri

3. Tidak lagi berpartisipasi atau berperan aktif dalam kegiatan kelompok

4. Terbukti melanggar aturan kelompok

5. Tidak mengindahkan kewajiban sebagai anggota

6. Berbuat sesuatu yang merugikan kelompok 


\section{Kas Kelompok}

1. Kas kelompok bersumber dari :
a. Iuran anggota berupa simpanan kelompok
b. Sumbangan-sumbangan yang tidak mengikat

\section{Anggaran Rumah Tangga Kelompok Tani Citawaya}

\section{Keanggotaan}

Keanggotaan Kelompok Tani Citawaya adalah :

1. Anggota kelompok tani adalah masyarakat Desa Talikuran I

2. Yang dimaksud dengan anggota adalah seorang petani yang tercatat secara resmi pada kelompok tani yang tergabung dalam kelompok tani Citawaya dan mengajukan permohonan dan persyaratan yang ditentukan

3. Permohonan untuk menjadi anggota kelompok tani Citawaya diputuskan oleh pengurus

\section{Pengurus}

1. Pengurus kelompok tani Citawaya sekurang-kurangnya terdiri dari 1 (satu) orang ketua, 1 (satu) orang sekretaris, dan 1 (satu) orang bendahara

2. Sebelum melaksanakan tugasnya pengurus kelompok tani Citawaya harus mengucapkan sumpah dan janji

3. Pengucapan sumpah dan janji pengurus dilaksanakan di depan musyawarah anggota kelompok tani Citawaya

4. Setiap pengurus setelah mengucapkan sumpah dan janji harus menandatangani berita acara pengucapan janji

\section{Musyawarah Anggota}

1. Pemilihan pengurus sebelumnya dilaksanakan secara musyawarah mufakat. Apabila belum ada kata mufakat, dapat dilakukan pengambilan suara terbanyak. Apabila ada dua calon pengurus atau lebih, dan ada suara yang sama, dapat diulangi kembali kecuali salah satu ada yang mengundurkan diri.

\section{Modal Anggota}

2. Simpanan pokok adalah simpanan anggota yang dibayarkan hanya sekali pada awal masuk yaitu sebesar Rp. 5.000,-

3. Simpanan wajib adalah simpanan anggota yang dibayarkan setiap pertemuan (bulanan) yaitu sebesar Rp. 2000,-

4. Pembayaran simpanan pokok dan simpanan wajib dapat melalui bendahara atau pengurus kelompok tani Citawaya

5. Simpanan pokok dan simpanan wajib yang telah terkumpul di kelompok tani akan dikembangkan sebagai simpan pinjam oleh pengurus

\section{Jenis Usaha}

Kelompok tani Citawaya menanam tiga jenis tanaman yaitu padi sawah, jagung, dan cabai. Alasan mereka memilih ketiga jenis tanaman ini untuk dijadikan usaha tani mereka adalah padi sawah merupakan salah satu bahan pokok pangan yang bisa diolah menjadi beras dan kemudian diolah menjadi nasi dan didukung dengan Wilayah mereka yang berada di daerah dataran tinggi (565 meter diatas permukaan laut) sehingga banyak sumber airnya. Jagung merupakan salah satu komoditi pangan pokok, dalam industri pangan jagung bisa dimanfaatkan sebagai pengganti beras dengan cara diolah menjadi nasi jagung, bubur jagung, dan aneka kuliner jagung lainnya karena jagung memiliki kandungan karbohidrat yang cukup tinggi dan baik untuk di konsumsi, dan yang terpenting jagung adalah bahan pokok dalam pembuatan pakan ternak, karena di Talikuran I dan beberapa desa yang ada di Kecamatan Sonder banyak masyarakat yang memiliki ternak sehingga inilah yang membuat usaha menanam jagung bisa sangat menguntungkan. Cabai sendiri merupakan salah satu tanaman musiman yang banyak kegunaannya. Petani menanam cabai juga sebagai kebutuhan mereka sehari-hari untuk itu kelompok tani Citawaya memilih cabai sebagai salah satu jenis tanaman yang mereka budidayakan. 


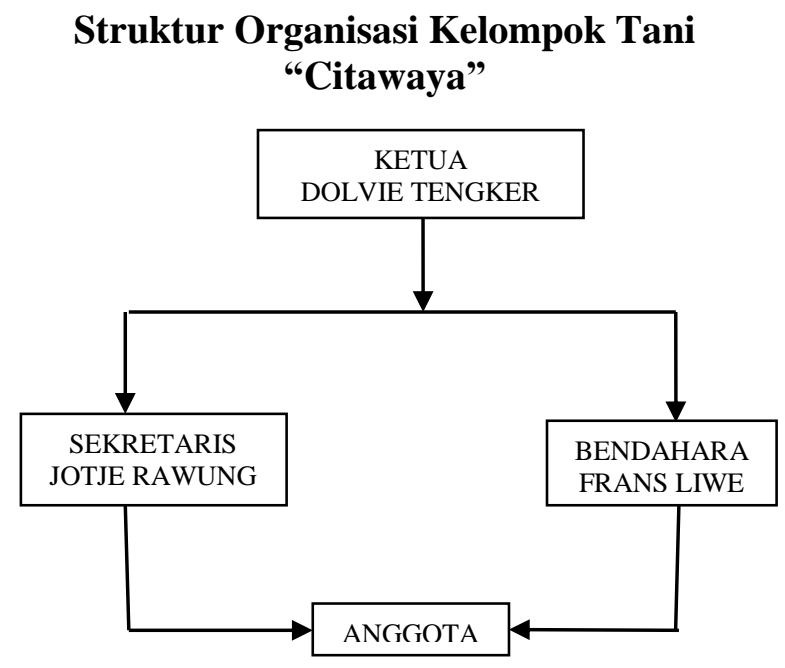

Gambar 3. Struktur Organisasi Kelompok Tani Citawaya Desa Talikuran I Kecamatan Sonder

\section{Karakteristik Responden}

\section{Umur Responden}

Kemampuan bekerja atau melakukan aktivitas secara fisik bahkan cara berpikir seseorang sangat dipengaruhi oleh faktor umur. Demikian juga dengan para petani dalam melakukan pekerjaanya, dimana mereka yang berumur muda kondisi fisiknya lebih kuat dari yang berumur lebih tua. Dari 20 responden petani yang diambil di Desa Talikuran I berdasarkan kelompok umur dapat dilihat pada Tabel 4. Tabel 4 menunjukkan bahwa sebagian besar responden berada pada kategori umur kisaran 58-62 tahun dengan persentase $50 \%$ dari 10 responden, dikuti dengan kisaran umur 53-57 dengan persentase $15 \%$ dari 3 responden, kisaran umur 48-52 dan 63-67 dengan persentase masingmasing $10 \%$ dari 2 responden, sedangkan kisaran umur 28-32, umur 33-37 dan umur 6872 juga memiliki persentase dan jumlah responden yang sama yaitu, persentase 5\% dari 1 responden.

\section{Tingkat Pendidikan Responden}

Pendidikan sangat penting dalam usaha peningkatan kualitas seseorang serta peningkatan intelektual dan untuk menambah ilmu penegtahuan dan wawasan seseorang. Tabel 5 menunjukkan tingkat pendidikan anggota kelompok tani "Citawaya". Tabel 5 menunjukkan bahwa responden memiliki pendidikan yang formal, dengan tingkat pendidikan terbanyak adalah SMP dengan jumlah responden 12 orang $(60 \%)$, Tingkat SMA memiliki 3 responden (15\%), dan di tingkat SD memiliki 5 responden dengan persentase $(25 \%)$.

\section{Skor Rata-Rata Modal Sosial Kelompok Tani Citawaya}

Indikator kepercayaan dalam modal sosial kelompok tani Citawaya yang mendapatkan skor tertinggi adalah pernyataan "ada kerjasama antar kelompok tani Citawaya dengan pemerintah" yang dimaksud dengan kerjasama yang baik dengan pemerintah yaitu kelompok tani Citawaya selalu mengikuti program yang dibuat pemerintah setiap binaan yang disampaikan oleh pemerintah karena pemerintah desa juga adalah merupakan Pembina kelompok tani Citawaya. kemudian diikuti dengan pernyataan "ada saling percaya dalam kelompok" memang ada saling percaya dalam kelompok tani ini, sebagai wujudnya ada simpan pinjam kelompok terhadap anggota dan kalau ada anggota yang membutuhkan pengurus tidak segan memberikan pinjaman dan anggota yang dipinjamkan mengembalikannya pada batas waktu yang ditentukan dan "saling memberikan pendapat atau masukan terhadap sesama anggota kelompok", dan "ada kerjasama yang baik dalam kelompok", sesama anggota juga saling memberikan pendapat mereka terkait usaha yang dijalankan seperti cara menanam yang baik atau inovasi-inovasi yang baru untuk kebaikan kelompok tani ini kemudian "dapat menerima pendapat orang lain" dengan pendapat serta inovasi yang disampaikan oleh anggota maka anggota yang lain juga pengurus menerima hal tersebut dengan alasan supaya kelompok tani ini bisa lebih berkembang lagi. Pada indikator ini diperoleh skor rata-rata 87 sehingga interpretasi nilai dalam indikator kepercayaan sangat tinggi dapat dilihat pada Tabel 6. 
$\overline{\mathrm{x}}=\frac{\sum \mathrm{xi}}{\mathrm{n}}=\frac{783}{9}=87$

Indikator norma sosial dalam modal sosial kelompok tani Citawaya yang mendapatkan skor tertinggi adalah pernyataan "anggota yang tidak taat aturan diberikan sanksi" anggota yang tidak taat aturan diberikan sanksi dengan tidak menerima bantuan kemudian kalau sudah melanggar aturan dengan merugikan kelompok maka anggota dapat diberhentikan dari keanggotaan kelompok tani Citawaya namun sampai saat ini belum pernah terjadi demikian, kemudian diikuti dengan pernyataan "sanksi membawa perubahan yang baik dalam kelompok" kemudian pernyataan "peraturan memberikan pengaruh yang baik terhadap kelompok" sanksi dan peraturan membawa perubahan yang baik dalam kelompok karena itulah yang menjadi acuan agar kelompok tani ini bisa menjadi kelompok yang berkembang sampai saat ini, dan pernyataan "ketaatan terhadap aturan", "masing-masing anggota tidak curang terhadap anggota lainnya" dan "ketua kelompok selalu berlaku adil terhadap anggota" pernyataan-pernyataan tersebut menunjukkan anggota taat terhadap aturan karena belum ada yang melanggar aturan sampai merugikan kelompok, masing-masing kelompok juga selalu menerima bantuan yang sama sehingga tidak curang dengan yang lain. Pada indikator ini diperoleh skor rata-rata 83.66 sehingga interpretasi nilai dalam indikator norma sosial sangat tinggi. Indikator norma sosial dalam modal sosial kelompok tani Citawaya dapat dilihat pada Tabel 7 . $\overline{\mathrm{x}}=\frac{\sum \mathrm{xi}}{\mathrm{n}}=\frac{753}{9}=83.66$

Indikator jaringan sosial dalam modal sosial kelompok tani Citawaya yang mendapatkan skor tertinggi adalah pernyataan "ada komunikasi yang baik antara kelompok tani Citawaya dengan pemerintah", komunikasi antara kelompok dengan pemerintah berjalan dengan baik karena memang ketua kelompok juga adalah kaur pemerintah Desa dan juga kegiatan kelompok banyak hubungannya dengan pemerintah Desa wujudnya kalau ada lomba tingkat kabupaten maka kelompok tani Citawaya selalu menjadi kelompok yang diutus, ini menunjukkan bahwa kelompok tani Citawaya menjalin hubungan yang baik dengan pemerintah sehingga komunikasi berjalan dengan lancar, kemudian pada pernyataan "ada komunikasi yang baik dalam kelompok", komunikasi dalam kelompok berjalan dengan baik karena setiap anggota diberikan hak dalam mengemukakan pendapat dan masukkan bukan hanya pada saat rapat tapi juga dalam pertemuan yang terjadi seharihari, pada pernyataan "ada komunikasi yang baik antara kelompok tani Citawaya dengan masyarakat termasuk pembeli hasil usaha tani" komunikasi berjalan dengan baik dan lancar, pembeli biasanya sudah menjadi langganan pada musim panen padi, jagung, dan cabai, bisa langsung kepada setiap anggota atau juga bisa lewat pengurus sehingga komunikasi selalu berjalan dengan baik. Pada indikator ini diperoleh skor ratarata 84.66 dan mendapat interpretasi sangat tinggi. Indikator jaringan sosial dalam modal sosial kelompok tani Citawaya dapat dilihat pada Tabel 8.

$\overline{\mathrm{x}}=\frac{\sum \mathrm{xi}}{\mathrm{n}}=\frac{254}{3}=84.66$

Indikator nilai-nilai sosial dalam modal sosial kelompok tani Citawaya yang mendapatkan skor tertinggi adalah pernyataan "kelompok tani Citawaya adalah kelompok tani yang berkembang di Desa Talikuran I", memang benar kelompok tani ini adalah yang berkembang di Desa Talikuran I, karena dari keempat kelompok tani yang ada kelompok tani Citawaya adalah kelompok tani yang sudah ada sejak lama yaitu tahun 1998 dan tingkatannya madya sementara yang lain tingkatannya masih pemula, kemudian diikuti dengan pernyataan "semua anggota kelompok rajin dalam menjalankan kegiatan usaha tani", dan anggota kelompok tidak putus asa dalam menjalankan kegiatan usaha tani" setiap anggota kelompok rajin dalam menjalankan usaha tani, tidak putus asa karena itu merupakan 
mata pencaharian mereka dan "masing-masing anggota dapat menyatukan perbedaan yang ada" dengan perbedaan yang ada tidak membuat kelompok tani ini terpecah bela tetapi itulah yang membuat kelompok tani ini tetap bertahan karena banyak informasi yang diperoleh dari perbedaan yang ada pada mereka. Pernyataan "pernah mendapatkan penghargaan", penghargaan yang pernah didapat kelompok tani Citawaya yaitu penghargaan sebagai kelompok tani yang berkembang dan kelompok tani yang masih bertahan sejak tahun 1997 hingga sekarang, dan pernyataan "kelompok pernah mencapai prestasi", prestasi yang pernah dicapai kelompok yaitu Juara 1 kelompok tani teladan dan penyuluh pertanian teladan tingkat kabupaten (1 orang utusan kelompok tani Citawaya). Pada indikator nilainilai sosial diperoleh skor rata-rata 83.88 dan mendapat interpretasi sangat tinggi.

$\overline{\mathrm{x}}=\frac{\sum \mathrm{xi}}{\mathrm{n}}=\frac{755}{9}=83.88$

Indikator timbal balik yang mendapatkan skor tertinggi adalah pernyataan "saling membantu dengan masyarakat sekitar" ini menunjukkan bahwa ada saling membantu dengan masyarakat sekitar, seperti bergotong royong saling membantu membersihkan lingkungan sekitar dan kebun tempat melakukan kegiatan usaha tani, kemudian diikuti dengan pernyataan "saling mendorong kearah yang lebih baik terhadap sesama anggota" ini berarti setiap anggota kelompok tani saling peduli dengan anggota kelompok tani lainnya sehingga mereka saling mengingatkan dan saling mendorong kearah yang lebih baik, dan pernyataan "peka terhadap kebutuhan anggota kelompok tani lain" jika anggota kelompok tani lain yang membutuhkan benih dan pupuk maka anggota kelompok tani Citawaya meminjamkannya kemudian nanti dikembalikan, dan "peka terhadap kebutuhan masyarakat sekitar" wujudnya jika pada musim panen masyarakat belum memiliki cukup uang untuk membeli beras, jagung, dan cabai maka anggota akan memberikannya terlebih dahulu, dan bayarannya nanti menyusul dengan batas waktu paling lama satu minggu, dengan begitu mereka sudah membantu masyarakat yang membutuhkan. Pada indikator ini diperoleh skor rata-rata 84.9 dan interpretasinya sangat tinggi.

$\overline{\mathrm{x}}=\frac{\sum \mathrm{xi}}{\mathrm{n}}=\frac{849}{10}=84.9$
Untuk mengetahui modal sosial kelompok tani Citawaya di Desa Talikuran I, dihitung jumlah keseluruhan skor pada setiap kriterium, dan sesuai hasil penelitian skor mencapai 3.394. Dalam penelitian ini jumlah skor ideal 4.000 (kategori sangat tinggi) dan jumlah skor terendah yaitu 800 (sangat rendah). Berdasarkan data yang dihimpun dari 40 indikator pernyataan yang diajukan kepada 20 orang responden, diperoleh total skor 3.394. Secara persentase, angka indeks modal sosial kelompok tani Citawaya di Desa Talikuran I sebagai berikut:

Modal Sosial Kelompok Tani

$=\frac{\text { Jumlah skor hasil pengumpulan data }}{\text { Jumlah skor ideal (tertinggi) }} \times 100 \%$

$=\frac{3.394}{4.000} \times 100 \%=85 \%$

Berdasarkan hasil analisis menggunakan skala likert, indeks modal sosial kelompok tani Citawaya di Desa Talikuran I berada pada titik 85\% dan tergolong dalam kategori sangat tinggi. Hal ini berarti bahwa kelompok tani Citawaya memiliki modal sosial yaitu mengenai kepercayaan, norma sosial, jaringan sosial, nilainilai sosial, dan timbal balik.

Tabel 1. Jumlah Penduduk menurut Jenis Kelamin di Desa Talikuran I Tahun 2017

\begin{tabular}{llll}
\hline No & Jenis Kelamin & Jumlah & Presentase \% \\
\hline 1. & Laki-laki & 376 & 53 \\
2. & Perempuan & 336 & 47 \\
\hline \multicolumn{2}{l}{ Total } & 712 & 100 \\
\hline
\end{tabular}

Sumber : Kantor Desa Talikuran I, 2017

Tabel 2. Jumlah Penduduk menurut Tingkat Pendidikan di Desa Talikuran I Tahun 2017

\begin{tabular}{|c|c|c|c|}
\hline No & $\begin{array}{l}\text { Tingkat } \\
\text { Pendidikan }\end{array}$ & Jumlah & $\begin{array}{c}\text { Presentase } \\
\%\end{array}$ \\
\hline 1. & $\begin{array}{l}\text { Belum/Tidak } \\
\text { Sekolah }\end{array}$ & 30 & 14 \\
\hline 2. & $\mathrm{SD} /$ Sederajat & 70 & 33,49 \\
\hline 3. & SMP/Sederajat & 30 & 14,35 \\
\hline 4. & SMA/Sederajat & 35 & 16,75 \\
\hline 5. & $\begin{array}{l}\text { Sedang di } \\
\text { Perguruan Tinggi }\end{array}$ & 25 & 11,96 \\
\hline 6. & $\begin{array}{l}\text { Tamat } \\
\text { Diploma/Akademik }\end{array}$ & 3 & 1,44 \\
\hline 7. & Tamat S1 & 15 & 7,18 \\
\hline 8. & Tamat S2 & 1 & 0,48 \\
\hline & Total & 209 & 100 \\
\hline
\end{tabular}

Sumber : Kantor Desa Talikuran I, 2017 
Tabel 3. Jumlah Penduduk menurut Pekerjaan di Desa Talikuran I

\begin{tabular}{|c|c|c|c|}
\hline No & Mata pencaharian & Jumlah & Presentase \% \\
\hline 1. & PNS & 5 & 1,5 \\
\hline 2. & Perawat/Bidan & 4 & 1,2 \\
\hline 3. & Dokter & 2 & 0,6 \\
\hline 4. & Pensiunan & 6 & 1,8 \\
\hline 5. & Karyawan BUMN & 1 & 0,3 \\
\hline 6. & Karyawan Swasta & 20 & 6,1 \\
\hline 7. & Petani & 110 & 34 \\
\hline 8. & Buruh Tani & 42 & 13 \\
\hline 9. & Peternak & 66 & 22 \\
\hline 10. & Buruh Ternak & 2 & 0,6 \\
\hline 11. & Pedagang & 9 & 2,9 \\
\hline 12. & Tukang Bangunan & 30 & 9 \\
\hline 13. & Tukang Jahit & 1 & 0,3 \\
\hline 14. & Tukang Listrik & 1 & 03 \\
\hline 15. & Industri Kecil & 3 & 0,9 \\
\hline 16. & Transportasi & 12 & 3,7 \\
\hline 17. & Pengangguran & 8 & 2,4 \\
\hline 18. & TKI/TKW & 3 & 0,9 \\
\hline 19. & Perbengkelan & 2 & 0,6 \\
\hline Tota & & 327 & 100 \\
\hline
\end{tabular}

Sumber : Kantor Desa Talikuran I, 2017

Tabel 4. Jumlah Anggota Kelompok Tani "Citawaya" berdasarkan Kelompok Umur di Desa Talikuran I

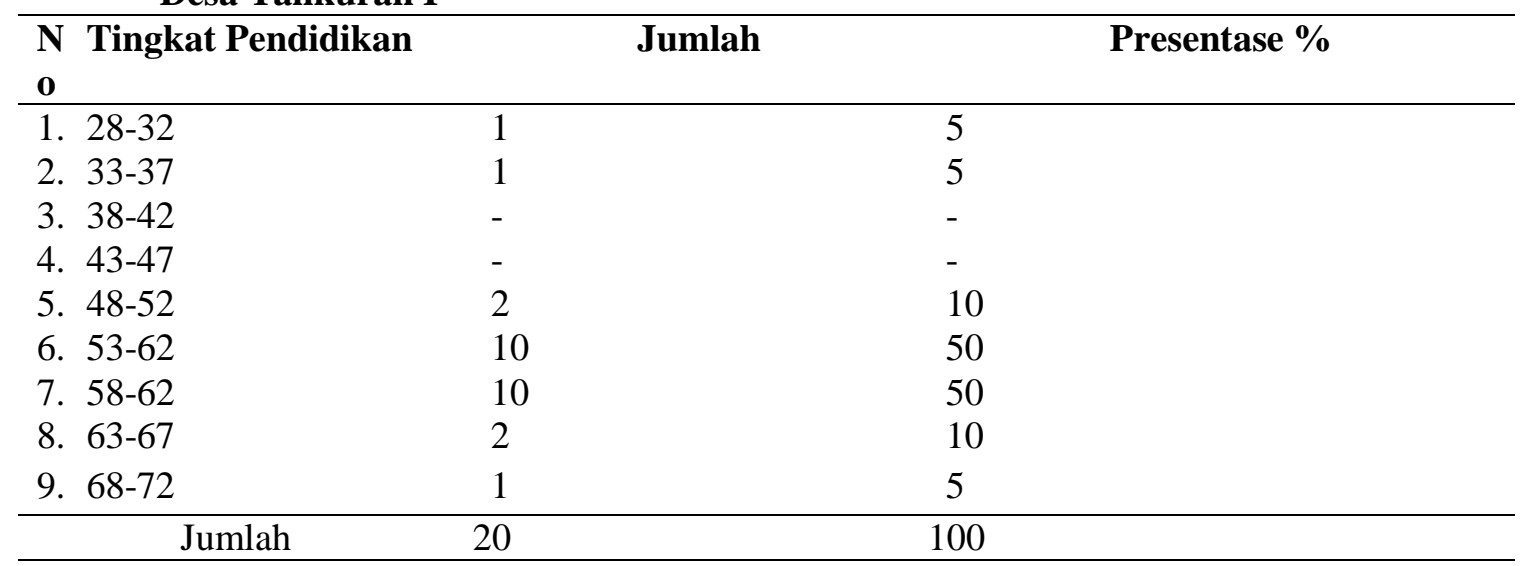

Sumber : Diolah dari data primer, 2017

Tabel 5. Anggota Kelompok Tani "Citawaya" berdasarkan pendidikan di Desa Talikura I

\begin{tabular}{lccc}
\hline No & Jenis Kelamin & Jumlah & Presentase \% \\
\hline 1. & SMA & 3 & 15 \\
2. & SMP & 12 & 60 \\
3. & & & 25 \\
4. & SD & 5 & 100 \\
\hline
\end{tabular}

Sumber : Kantor Desa Talikuran I, 2017 
Tabel 6. Skor Rata-rata Modal Kelompok Tani "Citawaya"

\begin{tabular}{|c|c|c|c|}
\hline No & Kepercayaan & Total skor & Interpretasi \\
\hline 1. & $\begin{array}{l}\text { Ada saling percaya dalam } \\
\text { kelompok }\end{array}$ & 89 & Sangat Tinggi \\
\hline 2. & $\begin{array}{l}\text { Ada saling percaya antar } \\
\text { kelompok tani yang lain }\end{array}$ & 82 & Sangat Tinggi \\
\hline 3. & $\begin{array}{l}\text { Ada kerjasama antar } \\
\text { kelompok tani Citawaya } \\
\text { dengan pemerintah }\end{array}$ & 95 & Sangat Tinggi \\
\hline 4. & $\begin{array}{l}\text { Masing-masing Anggota } \\
\text { memiliki sikap jujur }\end{array}$ & 83 & Sangat Tinggi \\
\hline 5. & $\begin{array}{l}\text { Ada kerjasama antar } \\
\text { kelompok }\end{array}$ & 88 & Sangat Tinggi \\
\hline 6. & $\begin{array}{l}\text { Tidak ada anggota kelompok } \\
\text { yang dirugikan }\end{array}$ & 86 & Sangat Tinggi \\
\hline 7. & $\begin{array}{l}\text { Saling memberikan pendapat } \\
\text { atau masukan terhadap sesama } \\
\text { anggota kelompok }\end{array}$ & 89 & Sangat Tinggi \\
\hline 8. & $\begin{array}{l}\text { Masing-masing anggota } \\
\text { kelompok memiliki sifat } \\
\text { terbuka satu sama lain }\end{array}$ & 84 & Sangat Tinggi \\
\hline 9. & $\begin{array}{l}\text { Dapat menerima pendapat } \\
\text { orang lain }\end{array}$ & 87 & Sangat Tinggi \\
\hline & Jumlah & 783 & \\
\hline
\end{tabular}

Tabel 7. Skor Rata-rata Norma Sosial

\begin{tabular}{llrl}
\hline No & Kepercayaan & Total skor & Interpretasi \\
\hline 1. & Ada saling percaya dalam kelompok & 89 & Sangat Tinggi \\
2. & Ada saling percaya antar kelompok tani yang lain & 82 & Sangat Tinggi \\
3. & Ada kerjasama antar kelompok tani Citawaya dengan pemerintah & 95 & Sangat Tinggi \\
4. & Masing-masing Anggota memiliki sikap jujur & 83 & Sangat Tinggi \\
5. & Ada kerjasama antar kelompok & 88 & Sangat Tinggi \\
6. & Tidak ada anggota kelompok yang dirugikan & 86 & Sangat Tinggi \\
7. & Saling memberikan pendapat atau masukan terhadap sesama & 89 & Sangat Tinggi \\
& anggota kelompok & & \\
8. & Masing-masing anggota kelompok memiliki sifat terbuka satu sama & 84 & Sangat Tinggi \\
& lain & & \\
9. & Dapat menerima pendapat orang lain & 87 & Sangat Tinggi \\
\hline & $\quad$ Jumlah & 783 & \\
\hline
\end{tabular}

Tabel 8. Skor Rata-rata Jaringan Sosial

\begin{tabular}{llcl}
\hline No & Kepercayaan & Total skor & \multicolumn{1}{c}{ Interpretasi } \\
\hline 1. & Ada komunikasi yang baik dalam kelompok & 84 & Sangat Tinggi \\
2. & $\begin{array}{l}\text { Ada komunikasi yang baik antara kelompok tani Citawaya } \\
\text { dengan masyarakat sudah termasuk pembeli hasil usaha tani }\end{array}$ & 80 & Tinggi \\
3. & $\begin{array}{l}\text { Ada komunikasi yang baik antara kelompok tani dengan } \\
\text { pemerintah }\end{array}$ & 90 & Sangat Tinggi \\
\hline & Jumlah & 254 & \\
\hline
\end{tabular}




\begin{tabular}{llll} 
Tabel 9. Skor Rata-rata Nilai Sosial & & \\
\hline N & Kepercayaan & Total skor & Interpretasi \\
$\mathbf{0}$ & & 84 & Sangat Tinggi \\
\hline 1. Aktifitas dalam kelompok berjalan dengan baik & 86 & Sangat Tinggi \\
2. Semua anggota kelompok rajin dalam menjalankan usaha tani & 86 & Sangat Tinggi \\
3. Anggota kelompok tidak putus asa dalam menjalankan usaha tani & 84 & Sangat Tinggi \\
4. Ada hubungan yang selaras/serasi dalam kelompok & 80 & Tinggi \\
5. Masing-masing anggota dapat menyatukan perbedaan yang ada & 83 & Sangat Tinggi \\
6. Ada keharmonisan dalam kelompok & 80 & Tinggi \\
7. Pernah mendapatkan penghargaan & 80 & Tinggi \\
8. Kelompok pernah mencapai prestasi & 92 & Sangat Tinggi \\
9. Kelompok tani Citawaya adalah kelompok tani yang berkembang di & & \\
\hline & Desa Talikuran I & 755 & \\
\hline \multicolumn{2}{l}{ Jumlah } &
\end{tabular}

\section{KESIMPULAN DAN SARAN}

\section{Kesimpulan}

Kelompok tani Citawaya di Desa Talikuran I memiliki modal sosial yang sangat tinggi dengan index modal sosial bernilai $85 \%$. Modal sosial tersebut berupa kepercayaan, norma sosial, jaringan sosial, nilai-nilai sosial, dan timbal balik. Modal sosial yang paling tinggi ada pada indikator kepercayaan, kemudian diikuti dengan indikator timbal balik, kemudian indikator jaringan sosial, kemudian indikator nilai-nilai sosial, dan terakhir indikator norma sosial. Tingginya modal sosial membuat kelompok tani Citawaya bisa bertahan sampai sekarang dan membawa perubahan yang baik dalam kelompok.

\section{Saran}

Saran dalam penelitian ini yaitu modal sosial kelompok tani Citawaya harus dipertahankan baik itu kepercayaan, norma sosial, jaringan sosial, nilai-nilai sosial, dan timbal balik. Supaya kelompok tani Citawaya tetap menjadi kelompok tani yang berkembang atau bisa menjadi kelompok tani yang maju dan menjadi panutan bagi kelompok tani lain yang ada di Desa Talikuran I.

\section{DAFTAR PUSTAKA}

Hakam. A (2015). Ekonomi Pembangunan Pertanian. PT Penerbit IPB Press. Bandung.

Mudiarta (2009). Jaringan Sosial (Networks) Dalam Pengembangan Sistem Agribisnis.

Nasdian F.T (2014). Pengembangan Masyarakat. Yayasan Pustaka Obor Indonesia. Jakarta.

Nasdian F.T (2015). Sosiologi Umum. Yayasan Pustaka Obor Indonesia. Jakarta.
Nuryanti, Swastika (2011). Peran Kelompok Tani Dalam Penerapan Teknologi Pertanian. Forum Penelitian Agro Ekonomi.

Pongtuluran Yonathan (2015). Manajemen Sumber Daya Alam dan Lingkungan. ANDI. Jogjakarta.

Pribadhi Prita Ayu (2011). Resiprositas Dalam Kehidupan Sosial Ekonomi Masyarakat. Universitas Negeri Semarang.

Purnamasari Irma (2008). Studi Partisipasi Masyarakat Dalam Perencanaan Pembangunan di Kecamatan Cibadak Kabupaten Sukabumi. Universitas Diponegoro Semarang.

Ridwan (2012). Pengantar Statistika Sosial. Bandung. Alfabeta.

Santoso W.M (2016). Ilmu Sosial Di Indonesia. Yayasan Pustaka Obor Indonesia. Jakarta.

Sarinah (2016). Ilmu Sosial Budaya Dasar. Deepublish.

Sudirah (2015). Modal Sosial Dan Pemberdayaan Masyarakat Desa Wisata.

Syahra. R (2003). Modal Sosial: Konsep Dan Aplikasi. Jurnal Masyarakat Dan Budaya.

Theresia A, Andini K.S, Nugraha P.G.P, Mardikanto T (2014). Pembanguna Berbasis Masyarakat. Alfabeta. Bandung.

Ulinnuha Z (2012). Strategi Peningkatan Produktivitas Petani Melalui Penguatan Modal Sosial. Universitas Diponegoro Semarang.

Verawati. S (2012). Peran Modal Sosial Dalam Strategi Industri Kreatif. Universitas Negeri Yogyaka. 